\title{
Weber's Critique of Advocacy in the Classroom: Critical Thinking and Civic Education
}

\author{
Mark Weaver, College of Wooster
}

\section{Weber on Advocacy}

Max Weber's "Science as a Vocafor examining some of the most important theoretical issues concerning advocacy in the classroom. In this 1918 speech, Weber addresses the problems and issues that will be confronted by those who are called to an academic profession, especially to the study of politics. For Weber, the issue of advocacy is one of the central issues of the academic profession, and he states his own position clearly.

It is said, and I agree, that politics is out of place in the lecture-room. It does not belong there on the part of the students.... Neither does politics, however, belong in the lecture room on the part of the docents, and when the docent is scientifically concerned with politics, it belongs there least of all.

In Weber's view, the goal of good teaching in political science is to help the student

to come to a position where the student may find the point from which, in terms of his ultimate ideals, he can take a stand. But the true teacher will beware of imposing from the platform any political position upon the student, whether it is expressed or suggested. "To let the facts speak for themselves" is the most unfair way of putting over a political position to the student (1946, 145-46).

Weber presents four interrelated arguments against advocacy in the political science classroom. The first argument is based upon his account of the fact/value distinction. The task of the teacher is to present the facts about political institutions and behaviors, not to become a "dema-

Mark Weaver is a professor of political science at the College of Wooster. He teaches courses in political theory, civil liberties, environmental politics, and women's sfudies. gogue" or "prophet" who prescribes certain values that are to guide political action. Of course, there have been numerous challenges to this account of the separation of facts and values, and many political science teachers today would argue that it is virtually impossible to exclude advocacy on the basis of a fact/value dichotomy.

However, Weber offers three other arguments against advocacy in addition to this argument concerning the separation of facts and values. These additional arguments are useful in clarifying what else is at stake in contemporary debates about advocacy in the political science classroom. Weber's second argument rests upon his recognition of the unequal power relationship between teacher and student. He begins with an encouragement of advocacy in the public sphere, which we might conceptualize in terms of an individual advocating political views while standing on a soapbox in the middle of a public park. In such a public space, the intended audience is free to criticize, to talk back, or simply to walk away. He then contrasts this with classroom advocacy:

In the lecture-room we stand opposite our audience, and it has to remain silent. I deem it irresponsible to exploit the circumstance that for the sake of their career [sic] the students have to attend a teacher's course while there is nobody present to oppose him with criticism. The task of the teacher is to serve the students with his knowledge and scientific experience and not to imprint upon them his personal political views (146).

Of course, many political scientists teach at institutions where the norm is no longer a professor lecturing from a podium to silent students. However, teachers who place chairs into a circle and participate in discussions with students do not elimi- nate the power relations inherent in the grading system and other structural features of contemporary academic institutions. It is, in part, this asymmetry of power that makes advocacy in the classroom, as opposed to the public park, so problematic.

Third, Weber draws a distinction between the role of the teacher and the role of a political (or moral) leader. In other words, he points to a distinction between the tasks of teaching about politics and the tasks of being a political leader. Only those filling the latter role have the obligation and authority to advocate specific political actions, choices, or ideologies. Political leadership is appropriately exercised in the public sphere outside the classroom where the leader draws followers by persuasion and example. In this public space, leaders and prospective leaders use advocacy to compete for followers through elections and the democratic process. Thus, it is, according to Weber, the task of the political leader, and not the political science teacher, to advocate a moral or political vision that is intended to guide individual or collective action.

At the same time, Weber does acknowledge that the political science teacher has a moral task distinct from that of the political leader. This points to Weber's fourth argument, that the primary task of the teacher is to prepare students to make their own choices, not to advocate what choices they should make. In short, he asserts that advocacy will inevitably shortcircuit the complex processes through which students become more independent and autonomous political thinkers. According to Weber, the teacher's job is to help students develop their own critical perspectives and to confront students with the difficult political choices they must make. This task, which is the central task of teaching in Weber's model, cannot be accom- 
plished if the teacher advocates the particular moral or political choices that students should make, or advocates a particular moral or ideological perspective that students are encouraged to adopt. In his words,

"The primary task of a useful teacher is to teach his students to recognize 'inconvenient' facts-I mean facts that are inconvenient for their party opinions" (147). The effective political science teacher does not advocate a particular position that all students should adopt, but rather develops independence and autonomy by teaching students how to engage in a longer term process of confronting those "inconvenient facts" that challenge their fundamental assumptions about themselves, the political world, and their role in it.

\section{Civic Education and Critical Thinking as Alternative Models of Advocacy}

I believe that Weber's critique of advocacy in the classroom remains a useful starting point for considering the issue in relation to the contemporary political science classroom. Yet, Weber does not specifically address one of the central elements that is common to recent treatments of advocacy in political science. While cautioning against advocacy, Weber failed to specify what is, and what should be, the relation between political science and the polity or between the study of politics and democracy. ${ }^{1}$ I want to consider two different models of political education that are frequently advanced or discussed in the pages of $P S$ and that do incorporate advocacy into the classroom as a response to this question of the discipline's responsibilities to the democratic polity. Both these models, the critical thinking model and the civic education model, are responses to the rise in apathy, the decline in political participation, and the decline in political literacy that are increasingly evident among our students and throughout U.S. society in general. ${ }^{2}$ Although both models do present advocacy in the political science classroom as a necessary response to a perceived crisis in democratic cul- ture and citizenship, they are very different when viewed through the lenses of Weber's objections to advocacy.

The critical thinking model emphasizes and incorporates advocacy into the political science classroom because advocacy is an essential and frequently misunderstood element of democratic politics. ${ }^{3}$ Put simply, this critical thinking model holds that students can be taught critical thinking skills in politics only by analyzing and engaging in political arguments. Indeed, some advocates of the critical thinking model define critical thinking as the ability to identify, evaluate, and articulate arguments (see, for example, Atwater 1991, 209). Defenders of this model argue that the teaching of critical thinking skills must displace the teaching of facts about politics if our democratic culture is to survive.

I contend that this critical thinking model incorporates advocacy in a way that is consistent with Weber's main arguments against advocacy in to differentiate their teaching role of promoting independence and autonomy from the leadership task of providing a moral, political, or ideological vision to guide student choice and conduct.

In contrast, the civic education model presents the political science classroom not only as a forum for advocating competing political ideas and ideologies to encourage students to take their own stands, but also as a proper avenue for the nurturing of citizenship. Thus, critical discussion is combined with activities that are designed to socialize students into the values, habits, and dispositions that promote patriotism, community, and good citizenship. ${ }^{5}$ In order to affect this transformation, civic education typically includes forms of political activity, service learning, or mandatory community service that reach beyond the classroom to integrate theory and practice. In short, this civic education model champions a type of political science classroom in which dispositions, atti-

\section{According to Weber, the teacher's job is to help students develop their own critical perspectives and to confront students with the difficult politi- cal choices they must make. This task cannot be accomplished if the teacher advocates the partic- ular moral or political choices that students}

should make, or advocates a particular moral or ideological perspective that students are encouraged to adopt.

the classroom. According to this model, the teacher presents the students with several different arguments or perspectives so that they will be forced to confront "inconvenient facts" and to reflect on their own assumptions, putting the students in a better position to make reflective choices among competing political and moral perspectives. ${ }^{4}$ Moreover, in this critical thinking model, teachers attempt to avoid using their positions of power in the classroom to advocate particular political ideologies, actions, or choices to their students. Thus, they attempt tudes, and behaviors are altered so that students will embrace a specific model of democratic politics assumed to sustain democratic culture and institutions.

I think that Weber's objections to advocacy in the classroom raise some important questions regarding the commitment to advocacy entailed by the civic education model. With regard to the issue of power in the classroom, Weber's insights demand that we ask if it is dangerous to consider the college political science classroom to be primarily an extension of the same education and 
socialization process, promoting particular habits, dispositions, and attitudes toward the state, that begins in kindergarten. Concerning the distinction between the tasks of political science teaching and political leadership, Weber's position requires that we ask whether the promotion of volunteerism (or other attitudes or behaviors perceived to be good for a democratic polity) is better left to former, current, and would-be presidents than made the central mission of the political science teacher. Finally, Weber's emphasis on student independence and autonomy force the question: Is there not a fundamental tension, if not an outright contradiction, between the attempt to socialize students into a particular mold of citizenship and the attempt to develop

\section{Notes}

1. Two thoughtful examinations of the relations among political science and democratic institutions and culture are Ricci's The Tragedy of Political Science (1984) and Ceaser's Liberal Democracy and Political Science (1990).

2. Bennett (1997) examined both the factors that contribute to this declining interest in politics as well as what we, as political scientists, might be able to do about it.

3. Illustrations of different versions of the critical thinking model that I am summarizing here in very simple terms are contained in Atwater (1991), Cohen (1993), and Luger and Scheuerman (1993).

4. As the proponents of the critical thinking model emphasize, the use of advocacy in students' ability to make choices for themselves?

Weber's 1918 speech on "Science as a Vocation" is especially relevant to contemporary discussions of advocacy in the political science classroom because it moves us beyond the pervasive tendency to pose the issues in terms of an artificial, abstract dichotomy between maintaining the discipline's hard-won professionalism and taking seriously the discipline's task of defending democracy. In contrast, Weber's analysis of advocacy places the discussion of the responsibilities of the teacher and the dynamics of the relationship between teachers and students at the center of the debate. His central contention is that political science teachers are responsible for helping students develop the skills they will need if they are to take an independent political stand, and that any type of advocacy that compromises this goal must be eschewed. In this model, the burden of proof is on the proponents of civic education to make their case, not simply by pointing to the problems now confronting the democratic polity, but also by demonstrating that their curricular proposals do not violate the central principles of responsible teaching and democratic choice. Thus, following Weber, I ask: On what basis are the proponents of civic education in the political science classroom today so much more optimistic of the results of such advocacy, for both teaching and for democracy, than was Weber in 1918 ? teaching U.S. politics is not simply a matter of turning the classroom into a debating society so that studying politics becomes more fun. What they champion is similar to the approach to teaching comparative political ideologies that Love presented in Dogmas and Dreams. Love advanced a model of "connected knowing," in which students come to understand and care about the perspectives of others by becoming effective advocates of the different ideological perspectives they study (1991, xix).

5. Examples of different versions of the simplified civic education model presented here include Barber and Battistoni (1993), Boyte (1993), Chesney and Feinstein (1993), and O'Connell and McKenzie (1995).

\section{References}

Atwater, Thomas. 1991. "Critical Thinking in Basic U.S. Government Classes." PS: Political Science and Politics 24(June): 20911.

Barber, Benjamin R., and Richard Battistoni. 1993. "A Season of Service: Introducing Service Learning into the Liberal Arts Curriculum." PS: Political Science and Politics 26 (June): $235-40$

Bennett, Stephen E. 1997. "Why Young Americans Hate Politics, and What We Should Do about It." PS: Political Science and Politics 30(March): 47-53.

Boyte, Harry C. 1993. "Civic Education as Public Leadership Development." PS: Political Science and Politics 26(December): 763-69.
Ceaser, James W. 1990. Liberal Democracy and Political Science. Baltimore: Johns Hopkins University Press.

Chesney, James D., and Otto Feinstein. 1993. "Making Political Activity a Requirement in Introductory Political Science Courses." PS: Political Science and Politics 26(September): 535-38.

Cohen, Mel. 1993. "Making Critical Thinking a Classroom Reality." PS: Political Science and Politics 26(June): 241-44.

Love, Nancy S., ed. 1991. Dogmas and Dreams: Political Ideologies in the Modern World. Chatham, NJ: Chatham House.

Luger, Stan, and William Scheuerman. 1993. "Teaching American Government." PS:
6. Barber and Battistoni attempted to resolve this tension between advocating patriotism and citizenship and developing critical thinking by incorporating critics of their vision of civic education into the course (1993, 238). I find this resolution unconvincing because the mere inclusion of "responsible" critics of service learning in the course materials cannot possibly balance the weight given to the advocates of civic education, who start from the very philosophical principles upon which the course and the overall program are based. The philosophical premise of the civic education program is that these alternative visions of democracy, citizenship, community, and politics are false or inadequate.
Political Science and Politics 26(December): $749-53$

O'Connell, Daniel W., and Robert H. McKenzie. 1995. "Teaching the Art of Public Deliberation-National Issues Forums in the Classroom." PS: Political Science and Politics 28(June): 230-231.

Ricci, David M. 1984. The Tragedy of Political Science: Politics, Scholarship, and Democracy. New Haven: Yale University Press.

Weber, Max. 1946. "Science as a Vocation." In From Max Weber: Essays in Sociology, ed. H.H. Gerth and C. Wright Mills. New York: Oxford University Press. 